
\title{
25 Research Square \\ Information Literacy of Nurses in Shaanxi Province, China: A Cross-sectional Descriptive and Multicentre Survey
}

\section{Chao Wu}

Air Force Medical University

Jiayong Fan

Air Force Medical University

Linyuan Zhang

Air Force Medical University

Yanling Du

Air Force medical University

Shizhe He

Air Force Medical University

Lirong $\mathrm{Yu}$

Xianyang Central hospital

Hongfang Chen

Shanxi Provincial Hospital of traditional Chinese medicine

Wei Jiang

Xi'an Tangdu Hospital of No4 Military Medical University

\section{Lei Shang}

Air Force Medical University

Hongjuan Lang ( $\triangle 906963251 @ q q . c o m)$

Air Force Medical University https://orcid.org/0000-0002-4761-024X

\section{Research article}

Keywords: China, Nurses, Information literacy, Hospitals of different levels

Posted Date: September 30th, 2020

DOI: https://doi.org/10.21203/rs.3.rs-57923/v1

License: (c) (i) This work is licensed under a Creative Commons Attribution 4.0 International License. Read Full License 


\section{Abstract}

Background: With the advent of the information age, rapid progress has been made in Chinese medical and health services. As the main force to give thorough, systematic and integral services for patients, nurses play an important role in the development of information-based medical care. However, there is a lack of research on the information literacy of nurses in the hospitals of different levels in China.

Methods: We selected 30 hospitals in Shaanxi Province by convenient sampling method and distributed 3,480 questionnaires from March to July 2020. The self-reported questionnaire included general information of nurses and their information literacy scale which was filled in the form of anonymity on the Internet. We then performed descriptive analyses, univariate analysis and multiple linear regression analysis on the collected data.

Results: We obtained 3,011 valid questionnaires, with the response rate of $94.71 \%(n=3,296)$. The total score of information literacy of 3,011 nurses was $114.18 \pm 18.62$, including $115.39 \pm 17.66$ for tertiary hospital nurses, $114.65 \pm 19.02$ for secondary hospital nurses and $105.00 \pm 18.68$ for primary hospital nurses $(F=33.755$, $P=0.000$ ). The nurses who were in primary hospital, with low education background or at older age, could not use database, had not participated in information literacy training, spent less spare time on learning, read less literature, had lower information literacy level (F®39.687, P凶0.000).

Conclusions: There are differences in nurses' information literacy among hospitals of different levels and several factors are associated with the information literacy. Since the information literacy of nurses in primary hospitals is the lowest, we should pay special attention to improving their information literacy, in particular. The government should strengthen information support and organize information literacy training. The hospitals should offer courses, lectures, seminars to improve the information literacy of nurses. Nurses should improve their information skills, read the latest professional literature, and constantly improve themselves.

\section{Background}

Along with the rapid development of computer applications and network communications technology, which will create a large amount of data every second, we have entered an era of big data [1, 2]. Since big data has become a new strategic resource, its potential value and growth rate are changing the way of human work, life and thinking [3,4]. Today digital healthcare has become the main direction in healthcare development [5]. With the long-term development of medical and health services, medical technology and health care facilities have been significantly improved. At the same time, it puts forward new requirements for clinical nurses to collect, process and use information [6].

Under environment of the multimedia and the network, information literacy is a basic ability for nurses in clinical nursing practice [7]. It refers to the ability to perceive information needs, access to information resources, evaluate information values, use and create information $[8,9]$. In the information-based nursing work, it is very important for nurses to analyze, process and use information efficiently $[10,11]$. A study of Chinese nurses shows that information capability is closely related to innovation behavior and work enthusiasm [12]. It can also help nurses to make clinical decision and improve their work efficiency [13]. In order to meet the challenge of big data era, it is urgent to improve the information literacy of clinical nurses [14]. 
Mokhtar et al. [15] found that $36.5 \%$ of nurses occasionally used medical subject headings for retrieval, and $26.1 \%$ of nurses never used them while at least $70 \%$ of nurses did not realize that they could use medical subject headings for more efficient retrieval, which greatly restricted the use of information. A survey of Canadian nurses indicated that approximately $25-38 \%$ had mastered information literacy skills in their professional practice [16]. The studies on information literacy of nurses in Hong Kong and Taiwan reported that their information literacy was at a low level $[17,18]$ which is not conducive to the acquisition and utilization of information, or improving work efficiency [19].

Although we know that information literacy is important for nurses, little is known regarding the information literacy of nurses in hospitals of different levels in Chinese mainland. Therefore, the purpose of the crosssectional descriptive and multicentre survey was to investigate the information literacy of nurses and its influencing factors, which may provide guidance for improving nurses' information literacy, work efficiency and quality, and effectively ensuring patients' safety.

\section{Methods}

\section{Study design}

This was a multicentre, cross-sectional descriptive study to investigate the information literacy and its influencing factors of nurses in hospitals of different levels in China, using a structured self-reported questionnaire.

\section{Setting and participants}

From March to July 2020, we selected 3,480 nurses from 5 tertiary hospitals, 7 secondary hospitals and 18 primary hospitals in Shaanxi Province. Participants were enrolled through a non-random, convenience sampling method. The inclusion criteria were the nurses who had obtained the nurse qualification certificate and engaged in clinical nursing work; the exclusion criteria were the nurses who were unwilling to participate in the investigation or were not on duty during the investigation.

\section{Data collection}

Before the formal investigation, the investigators received unified training. When the questionnaires were sent out, the participants were given unified guidance. Participants completed the questionnaire independently online, and the filling time was controlled within 30 minutes. A total of 3,480 questionnaires were distributed, and 3,011 valid questionnaires were collected, with an effective response rate of $86.52 \%$. Among the 3,480 participants, 184 nurses withdrew from the study; 263 questionnaires were not completed completely; and there were 22 questionnaires with high consistency, filling the same respond number for all items and were regarded as invalid questionnaires.

\section{Measures}

The questionnaire consists of three parts, including instruction, general information questionnaire and nurse information literacy questionnaire, with totally 42 questions. And the questionnaires were distributed in the form 


\section{General information questionnaire}

The general information questionnaire of nurses includes 12 items: age, working years, education background, position, professional title, residence, marital status, studying in spare time, using database to search literature, number of recent medical literature reading resently and the participation in information literacy training.

\section{Nurse information literacy questionnaire}

On the basis of Wadson's [16] research questionnaire of nurses' information literacy and an extensive review of literature, we translated and adapted the information literacy questionnaire through expert argumentation to make it more suitable for Chinese nurses. Through the pre-experiment, the questionnaire had good reliability and validity. It was a self-designed questionnaire including five dimensions: information awareness ( 8 items), information knowledge ( 6 items), information ability (4 items), information ethics (6 items) and information support ( 6 items). The scoring method used Likert 5 points, and the higher the score, the higher information literacy level. In this study, the Cronbach's alpha coefficient of this questionnaire was 0.957 , with the Cronbach's alpha coefficient of the five dimensions ranged from 0.872 to 0.939 , and the Content Validity Index was 0.915 .

\section{Data analysis}

We used SPSS 23.0 statistical software for statistical analysis. The enumeration data were expressed by the number and percentage, and the measurement data were expressed in the form of mean \pm standard deviation. Chi square test was used for baseline comparison of general data. T-test and ANOVA were used in univariate analysis. We used multiple linear regression analysis and all tests conducted were 2-sided, at a significant level of 0.05 .

\section{Ethical approval}

An ethics approval was not required because there was no unethical behaviours existed in the study according to the International Ethical Guidelines for Health-related Research Involving Humans and the article 2 of the ethical review of biomedical research involving human beings. We just conducted electronic questionnaire through email and were exempt from further ethics board approval since our study did not involve human clinical trails or animal experiments. And the ethics committee of the Air Force Medical University did not consider it necessary to approve.

\section{Results}

In this study, a total of 3,480 nurses were investigated and 3,011 valid questionnaires were collected, including 1,280 in tertiary hospitals, 1,485 in secondary hospitals and 246 in primary hospitals. The average age of the respondents was 30.77 years old ( $S D=5.78$; ranged 18 to 56 years old) and the average years of working was 8.53 years ( $S D=6.30$; ranged 1 months to 38 years). The other general information details are showed in Table 1 . 
Table 1

General information of participants

\begin{tabular}{|c|c|c|c|c|c|c|c|c|c|c|}
\hline \multirow[t]{2}{*}{ Characteristics } & \multicolumn{2}{|c|}{ Total sample } & \multicolumn{2}{|c|}{$\begin{array}{l}\text { Tertiary } \\
\text { hospital }\end{array}$} & \multicolumn{2}{|c|}{$\begin{array}{l}\text { Secondary } \\
\text { hospital }\end{array}$} & \multicolumn{2}{|c|}{$\begin{array}{l}\text { Primary } \\
\text { hospital }\end{array}$} & \multirow[t]{2}{*}{$F / K / c^{2}$} & \multirow[t]{2}{*}{$P$} \\
\hline & Mean & SD & Mean & SD & Mean & SD & Mean & SD & & \\
\hline Age & 30.77 & 5.78 & 30.63 & 5.63 & 30.74 & 5.96 & 31.64 & 5.43 & 3.215 & 0.040 \\
\hline \multirow[t]{2}{*}{$\begin{array}{l}\text { Years of } \\
\text { working }\end{array}$} & 8.53 & 6.30 & 8.35 & 6.20 & 8.56 & 6.47 & 9.29 & 5.71 & 2.311 & 0.099 \\
\hline & $\mathrm{N}$ & $\%$ & $\mathrm{~N}$ & $\%$ & $\mathrm{~N}$ & $\%$ & $\mathrm{~N}$ & $\%$ & & \\
\hline
\end{tabular}

Educational levels

\begin{tabular}{|c|c|c|c|c|c|c|c|c|c|c|}
\hline $\begin{array}{l}\text { Junior } \\
\text { college }\end{array}$ & 1,278 & 42.45 & 220 & 17.19 & 951 & 64.04 & 107 & 43.50 & 624.210 & $<0.001$ \\
\hline Undergraduate & 1,720 & 57.12 & 1,047 & 81.80 & 534 & 35.96 & 139 & 56.50 & & \\
\hline $\begin{array}{l}\text { Master } \\
\text { degree or } \\
\text { above }\end{array}$ & 13 & 0.43 & 13 & 1.02 & - & - & - & - & & \\
\hline
\end{tabular}

Place of residence

$\begin{array}{lllllllllll}\text { City } & 2,077 & 68.98 & 1,092 & 85.31 & 793 & 53.40 & 192 & 78.05 & 337.360 & <0.001 \\ \text { Countryside } & 934 & 31.02 & 188 & 14.69 & 692 & 46.60 & 54 & 21.95 & & \end{array}$

Relationship status

\begin{tabular}{|lllllllllll|} 
Single & 809 & 26.87 & 394 & 30.78 & 346 & 23.30 & 69 & 28.05 & 19.166 & $<0.001$ \\
\hline Married & 2,175 & 72.23 & 877 & 68.52 & 1,127 & 75.89 & 171 & 69.51 & & \\
$\begin{array}{c}\text { Widowed or } \\
\text { separated }\end{array}$ & 27 & 0.90 & 9 & 0.70 & 12 & 0.81 & 6 & 2.44 &
\end{tabular}

Title

\begin{tabular}{|c|c|c|c|c|c|c|c|c|c|c|}
\hline Nurse & 1,004 & 33.34 & 328 & 25.63 & 598 & 40.27 & 78 & 31.71 & 57.293 & $<0.001$ \\
\hline Senior nurse & 1,431 & 47.53 & 679 & 53.05 & 644 & 43.37 & 108 & 43.90 & & \\
\hline $\begin{array}{l}\text { Nurses-in- } \\
\text { charge }\end{array}$ & 526 & 17.47 & 248 & 19.38 & 218 & 14.68 & 60 & 24.39 & & \\
\hline $\begin{array}{l}\text { Co-chief } \\
\text { nurse or above }\end{array}$ & 50 & 1.66 & 25 & 1.95 & 25 & 1.68 & - & - & & \\
\hline \multicolumn{11}{|l|}{ Positions } \\
\hline Head nurse & 237 & 7.87 & 91 & 7.11 & 133 & 8.96 & 13 & 5.28 & 5.703 & 0.058 \\
\hline Nurse & 2,774 & 92.13 & 1,189 & 92.89 & 1,352 & 91.04 & 233 & 94.72 & & \\
\hline \multicolumn{11}{|c|}{ Professional knowledge acquiring in spare time } \\
\hline None & 98 & 3.25 & 26 & 2.03 & 44 & 2.96 & 28 & 11.38 & 16.073 & $<0.001$ \\
\hline
\end{tabular}




\begin{tabular}{|c|c|c|c|c|c|c|c|c|c|c|}
\hline Occasionally & 1,311 & 43.55 & 540 & 42.19 & 663 & 44.65 & 108 & 43.90 & & \\
\hline $\begin{array}{l}\text { When } \\
\text { required by } \\
\text { work }\end{array}$ & 1,169 & 38.82 & 558 & 43.59 & 526 & 35.42 & 85 & 34.55 & & \\
\hline $\begin{array}{l}\text { Most of the } \\
\text { time }\end{array}$ & 433 & 14.38 & 156 & 12.19 & 252 & 16.97 & 25 & 10.16 & & \\
\hline \multicolumn{11}{|c|}{ Use database to search literature } \\
\hline No & 437 & 14.51 & 138 & 10.78 & 240 & 16.16 & 59 & 23.98 & 76.134 & $<0.001$ \\
\hline Not really & 1,572 & 52.21 & 623 & 48.67 & 810 & 54.55 & 139 & 56.51 & & \\
\hline Yes & 1,002 & 33.28 & 519 & 40.55 & 435 & 29.29 & 48 & 19.51 & & \\
\hline \multicolumn{11}{|c|}{ Number of medical literature reading in the past month } \\
\hline None & 1466 & 48.69 & 626 & 48.91 & 681 & 45.86 & 159 & 64.63 & 32.723 & $<0.001$ \\
\hline $1-3$ & 1274 & 42.31 & 520 & 40.63 & 673 & 45.32 & 81 & 32.93 & & \\
\hline More than 3 & 271 & 9.00 & 134 & 10.47 & 131 & 8.82 & 6 & 2.44 & & \\
\hline \multicolumn{11}{|c|}{ Participate in information literacy training } \\
\hline Yes & 876 & 29.09 & 354 & 27.66 & 480 & 32.32 & 42 & 17.08 & 16.503 & $<0.001$ \\
\hline No & 1366 & 45.37 & 585 & 45.70 & 645 & 43.44 & 136 & 55.28 & & \\
\hline Unclear & 769 & 25.54 & 341 & 26.64 & 360 & 24.24 & 68 & 27.64 & & \\
\hline
\end{tabular}

In Table 2, the information literacy scores of nurses with different general information in these hospitals showed that there were statistically significant differences in the scores of information literacy of nurses with different educational background, residence, marital status, position, professional knowledge acquiring in spare time, using database to consult literature, number of recent literature reading and whether or not to participate in information literacy training $(P<0.05)$. The specific differences of information literacy scores of nurses in different general information are shown in Table 2. 
Table 2

Comparison of information literacy scores of nurses with different general information in different level hospitals

\begin{tabular}{|c|c|c|c|c|}
\hline Characteristics & Total sample & Tertiary hospital & Secondary hospital & Primary hospital \\
\hline \multicolumn{5}{|l|}{ Age } \\
\hline$<26$ & $115.68 \pm 19.07^{\mathrm{bc}}$ & $118.64 \pm 16.64^{a b c}$ & $115.13 \pm 19.65$ & $101.40 \pm 22.24$ \\
\hline $26-30$ & $114.62 \pm 18.82$ & $115.00 \pm 18.45$ & $115.76 \pm 18.81$ & $103.56 \pm 17.88$ \\
\hline $31-35$ & $113.28 \pm 18.06$ & $114.23 \pm 17.13$ & $113.62 \pm 18.84$ & $106.46 \pm 17.64$ \\
\hline$>35$ & $113.04 \pm 18.47$ & $114.87 \pm 17.37$ & $113.17 \pm 18.97$ & $107.15 \pm 18.62$ \\
\hline$F$-values & 2.660 & 3.169 & 1.628 & 1.012 \\
\hline$P$ & 0.047 & 0.024 & 0.181 & 0.388 \\
\hline \multicolumn{5}{|l|}{ Years of working } \\
\hline$<3$ & $115.76 \pm 18.67$ & $118.70 \pm 16.87^{b}$ & $115.29 \pm 18.97$ & $100.69 \pm 20.11$ \\
\hline $3-5$ & $114.88 \pm 18.91$ & $115.54 \pm 18.12$ & $116.28 \pm 18.57$ & $100.70 \pm 20.23$ \\
\hline $6-10$ & $113.16 \pm 18.63$ & $113.84 \pm 18.03$ & $113.44 \pm 19.11$ & $105.83 \pm 18.11$ \\
\hline$>10$ & $114.06 \pm 18.32$ & $115.60 \pm 16.97$ & $114.38 \pm 19.26$ & $107.83 \pm 17.47$ \\
\hline$F$-values & 2.489 & 3.666 & 1.649 & 2.248 \\
\hline$P$ & 0.059 & 0.012 & 0.176 & 0.083 \\
\hline \multicolumn{5}{|l|}{ Educational levels } \\
\hline Junior college & $113.06 \pm 19.56^{a b}$ & $116.47 \pm 18.03$ & $113.86 \pm 19.19$ & $98.97 \pm 20.22$ \\
\hline Undergraduate & $114.94 \pm 17.85$ & $115.06 \pm 17.56$ & $116.07 \pm 18.63$ & $109.65 \pm 15.99$ \\
\hline Master degree or above & $123.77 \pm 17.89$ & $123.77 \pm 17.89$ & - & - \\
\hline$F$-values & 5.470 & 2.061 & 4.660 & 21.380 \\
\hline$P$ & 0.004 & 0.128 & 0.031 & $<0.001$ \\
\hline \multicolumn{5}{|l|}{ Place of residence } \\
\hline City & $114.91 \pm 18.19$ & $115.43 \pm 17.63$ & $115.88 \pm 18.74$ & $108.01 \pm 17.65$ \\
\hline Countryside & $112.54 \pm 19.46$ & $115.16 \pm 17.87$ & $113.25 \pm 19.25$ & $94.33 \pm 18.49$ \\
\hline$t$-values & 3.242 & 0.188 & 2.667 & 4.975 \\
\hline$P$ & 0.001 & 0.851 & 0.008 & $<0.001$ \\
\hline \multicolumn{5}{|l|}{ Relationship status } \\
\hline Single & $115.48 \pm 18.40 a b$ & $117.79 \pm 17.13^{a b}$ & $115.03 \pm 18.85$ & $104.49 \pm 19.24$ \\
\hline Married & $113.79 \pm 18.58$ & $114.46 \pm 17.67$ & $114.52 \pm 19.04$ & $105.54 \pm 18.22$ \\
\hline
\end{tabular}




\begin{tabular}{|c|c|c|c|c|}
\hline Widowed or separated & $106.33 \pm 24.96$ & $100.89 \pm 25.08$ & $115.75 \pm 22.98$ & $95.67 \pm 25.84$ \\
\hline$F$-values & 4.849 & 7.985 & 0.115 & 0.844 \\
\hline$P$ & 0.008 & $<0.001$ & 0.891 & 0.431 \\
\hline \multicolumn{5}{|l|}{ Title } \\
\hline Nurse & $113.98 \pm 19.56$ & $116.80 \pm 17.23$ & $114.58 \pm 19.61$ & $97.46 \pm 20.64^{\mathrm{ab}}$ \\
\hline Senior nurse & $114.16 \pm 18.45$ & $114.66 \pm 18.30$ & $114.97 \pm 18.75$ & $106.17 \pm 15.70$ \\
\hline Nures-in-charge & $114.40 \pm 17.55$ & $115.58 \pm 16.74$ & $113.53 \pm 18.41$ & $112.72 \pm 17.56$ \\
\hline Co-chief nurse or above & $116.40 \pm 15.21$ & $114.76 \pm 13.73$ & $118.04 \pm 16.67$ & - \\
\hline$F$-values & 0.303 & 1.100 & 0.579 & 12.802 \\
\hline$P$ & 0.823 & 0.348 & 0.629 & $<0.001$ \\
\hline \multicolumn{5}{|l|}{ Positions } \\
\hline Head nurse & $116.58 \pm 15.54$ & $117.00 \pm 14.52$ & $116.39 \pm 16.09$ & $115.62 \pm 17.91$ \\
\hline Nurse & $113.97 \pm 18.85$ & $115.27 \pm 17.88$ & $114.48 \pm 19.28$ & $104.41 \pm 18.59$ \\
\hline$t$-values & 2.072 & 0.903 & 1.105 & 2.119 \\
\hline$P$ & 0.038 & 0.367 & 0.270 & 0.035 \\
\hline \multicolumn{5}{|c|}{ Professional knowledge acquiring in spare time } \\
\hline None & $98.62 \pm 23.24 \mathrm{abc}$ & $106.12 \pm 20.84^{a b c}$ & $105.61 \pm 23.64 \mathrm{abc}$ & $80.68 \pm 13.44 \mathrm{abc}$ \\
\hline Occasionally & $112.53 \pm 18.49$ & $113.90 \pm 17.77$ & $113.06 \pm 18.95$ & $102.35 \pm 16.01$ \\
\hline When required by work & $113.86 \pm 17.46$ & $114.22 \pm 16.66$ & $113.70 \pm 18.53$ & $112.53 \pm 15.85$ \\
\hline Most of the time & $123.55 \pm 16.81$ & $126.26 \pm 16.19$ & $122.40 \pm 17.12$ & $118.12 \pm 15.38$ \\
\hline$F$-values & 66.985 & 25.591 & 19.979 & 36.101 \\
\hline$P$ & $<0.001$ & $<0.001$ & $<0.001$ & $<0.001$ \\
\hline \multicolumn{5}{|c|}{ Use database to search literature } \\
\hline No & $107.97 \pm 20.26^{\mathrm{ab}}$ & $108.88 \pm 18.71^{a b}$ & $110.03 \pm 20.38^{b}$ & $97.51 \pm 20.44^{\mathrm{ab}}$ \\
\hline Not really & $112.22 \pm 17.53$ & $113.53 \pm 17.14$ & $112.38 \pm 17.69$ & $105.40 \pm 16.85$ \\
\hline Yes & $119.96 \pm 18.05$ & $119.35 \pm 17.14$ & $121.44 \pm 18.89$ & $113.06 \pm 18.25$ \\
\hline$F$-values & 85.711 & 26.898 & 42.903 & 9.917 \\
\hline$P$ & $<0.001$ & $<0.001$ & $<0.001$ & $<0.001$ \\
\hline \multicolumn{5}{|c|}{ Number of medical literatures reading in the past month } \\
\hline None & $110.13 \pm 18.45^{a b}$ & $112.33 \pm 17.61 \mathrm{ab}$ & $110.18 \pm 18.58 \mathrm{ab}$ & $101.26 \pm 18.56^{\mathrm{a}}$ \\
\hline $1-3$ & $117.34 \pm 17.88$ & $117.85 \pm 17.18$ & $117.65 \pm 18.46$ & $111.60 \pm 16.63$ \\
\hline
\end{tabular}




\begin{tabular}{|c|c|c|c|c|}
\hline More than 3 & $121.18 \pm 18.08$ & $120.13 \pm 17.31$ & $122.53 \pm 18.65$ & $115.17 \pm 22.76$ \\
\hline$F$-values & 75.788 & 19.814 & 40.481 & 9.795 \\
\hline$P$ & $<0.001$ & $<0.001$ & $<0.001$ & $<0.001$ \\
\hline \multicolumn{5}{|c|}{ Participate in information literacy training } \\
\hline Yes & $120.54 \pm 18.44^{a b}$ & $122.10 \pm 17.64^{a b}$ & $119.68 \pm 19.03^{a b}$ & $117.19 \pm 17.37^{a b}$ \\
\hline No & $111.65 \pm 17.73$ & $112.77 \pm 16.80$ & $112.15 \pm 18.29$ & $104.46 \pm 17.41$ \\
\hline Unclear & $111.43 \pm 18.67$ & $112.93 \pm 17.34$ & $112.43 \pm 19.02$ & $98.56 \pm 18.59$ \\
\hline$F$-values & 75.595 & 37.301 & 25.598 & 14.470 \\
\hline$P$ & $<0.001$ & $<0.001$ & $<0.001$ & $<0.001$ \\
\hline \multicolumn{5}{|c|}{ Abbreviation: ${ }^{\text {a: }}$ Comparison of the first and second items $(P<0.05)$} \\
\hline \multicolumn{5}{|c|}{ b: Comparison of the first and third items $(P<0.05)$} \\
\hline \multicolumn{5}{|c|}{ c: Comparison of the first and fourth items $(P<0.05)$} \\
\hline
\end{tabular}

In Table 3, there were statistically significant differences in the total score of nurses' information literacy and the scores of its five dimensions among these hospitals $(P<0.001)$. The results of further pairwise comparison showed that the total score and the scores of five dimensions of nurses in tertiary hospitals were significantly different from those in primary hospitals $(P<0.001)$.

Table 3

The total score of information literacy of nurses and the scores of each dimension

\begin{tabular}{|lcclc|}
\hline & Total sample & Tertiary hospital & Secondary hospital & Primary hospital \\
\hline Information literacy & $114.18 \pm 18.62$ & $115.39 \pm 17.66^{\mathrm{b}}$ & $114.65 \pm 19.02$ & $105.00 \pm 18.68$ \\
\hline Information consciousness & $34.76 \pm 5.28$ & $35.06 \pm 4.96^{\mathrm{b}}$ & $34.90 \pm 5.14$ & $32.35 \pm 6.95$ \\
\hline Information knowledge & $19.56 \pm 5.29$ & $19.86 \pm 5.03^{\mathrm{b}}$ & $19.62 \pm 5.53$ & $17.63 \pm 4.70$ \\
\hline Information capability & $13.74 \pm 3.33$ & $13.81 \pm 3.22^{\mathrm{b}}$ & $13.91 \pm 3.42$ & $12.35 \pm 3.13$ \\
\hline Information ethics & $24.09 \pm 4.49$ & $24.34 \pm 4.32^{\mathrm{b}}$ & $24.07 \pm 4.60$ & $22.98 \pm 4.45$ \\
\hline $\begin{array}{l}\text { Information support } \\
\text { Abbreviation: }{ }^{\mathrm{a}} \text { : Compared with Secondary hospital }(P<0.001)\end{array}$ & & $19.69 \pm 4.45$ \\
\hline
\end{tabular}


In Table 4, we assign values to the arguments. In Table 5, the multiple linear regression equation of 3,011 nurses' information literacy showed that age, education background, professional knowledge acquiring in spare time, using database to search literature, hospital grade, number of medical literature reading in the past month and participation in information literacy training entered the equation $(F=39.687, P=0.000)$.

Table 4

Assignment of independent variable

\begin{tabular}{|c|c|}
\hline Independent variable & Assignment \\
\hline Age & $\begin{array}{l}<26\left(Z_{1}=0, Z_{2}=0, Z_{3}=0\right) ; 26-30\left(Z_{1}=0, Z_{2}=0, Z_{3}=1\right) ; 31-35\left(Z_{1}=0, Z_{2}=1, Z_{3}=0\right) \\
>35\left(Z_{1}=1, Z_{2}=0, Z_{3}=0\right)\end{array}$ \\
\hline Years of working & $\begin{array}{l}<3\left(Z_{1}=0, Z_{2}=0, Z_{3}=0\right) ; 3-5\left(Z_{1}=0, Z_{2}=0, Z_{3}=1\right) ; 6-10\left(Z_{1}=0, Z_{2}=1, Z_{3}=0\right) \\
>10\left(Z_{1}=1, Z_{2}=0, Z_{3}=0\right)\end{array}$ \\
\hline Educational levels & $\begin{array}{l}\text { Junior college }\left(Z_{1}=0, Z_{2}=0\right) \text {; Undergraduate }\left(Z_{1}=0, Z_{2}=1\right) \text {; Master degree or } \\
\text { above }\left(Z_{1}=1, Z_{2}=0\right)\end{array}$ \\
\hline Place of residence & City=0; Countryside=1 \\
\hline Relationship status & $\begin{array}{l}\text { Single }\left(Z_{1}=0, Z_{2}=0\right) ; \text { Married }\left(Z_{1}=0, Z_{2}=1\right) ; \text { Widowed or separated }\left(Z_{1}=1 \text {, }\right. \\
\left.Z_{2}=0\right)\end{array}$ \\
\hline Title & $\begin{array}{l}\text { Nurse }\left(Z_{1}=0, Z_{2}=0, Z_{3}=0\right) ; \text { Senior nurse }\left(Z_{1}=0, Z_{2}=0, Z_{3}=1\right) ; \text { Nures-in-charge } \\
\left(Z_{1}=0, Z_{2}=1, Z_{3}=0\right) ; \text { Co-chief nurse or above }\left(Z_{1}=1, Z_{2}=0, Z_{3}=0\right)\end{array}$ \\
\hline Positions & Head nurse=0; Nurse=1 \\
\hline $\begin{array}{l}\text { Professional knowledge } \\
\text { acquiring in spare time }\end{array}$ & $\begin{array}{l}\text { None }\left(Z_{1}=0, Z_{2}=0, Z_{3}=0\right) ; \text { Occasionally }\left(Z_{1}=0, Z_{2}=0, Z_{3}=1\right) \text {; When required by } \\
\text { work }\left(Z_{1}=0, Z_{2}=1, Z_{3}=0\right) ; \text { Most of the time }\left(Z_{1}=1, Z_{2}=0, Z_{3}=0\right)\end{array}$ \\
\hline $\begin{array}{l}\text { Use database to search } \\
\text { literature }\end{array}$ & No $\left(Z_{1}=0, Z_{2}=0\right) ;$ Not really $\left(Z_{1}=0, Z_{2}=1\right)$; Yes $\left(Z_{1}=1, Z_{2}=0\right)$ \\
\hline $\begin{array}{l}\text { Number of medical literatures } \\
\text { reading in the past month }\end{array}$ & None $\left(Z_{1}=0, Z_{2}=0\right) ; 1-3\left(Z_{1}=0, Z_{2}=1\right)$; More than $3\left(Z_{1}=1, Z_{2}=0\right)$ \\
\hline $\begin{array}{l}\text { Participate in information } \\
\text { literacy training }\end{array}$ & Yes $\left(Z_{1}=0, Z_{2}=0\right) ;$ No $\left(Z_{1}=0, Z_{2}=1\right) ;$ Unclear $\left(Z_{1}=1, Z_{2}=0\right)$ \\
\hline Hospital grade & $\begin{array}{l}\text { Tertiary hospital }\left(Z_{1}=0, Z_{2}=0\right) \text {; Secondary hospital }\left(Z_{1}=0, Z_{2}=1\right) \text {; Primary } \\
\text { hospital }\left(Z_{1}=1, Z_{2}=0\right)\end{array}$ \\
\hline
\end{tabular}


Table 5

Multiple linear regression analysis of information literacy of nurses $(n=3,011)$

\begin{tabular}{|c|c|c|c|c|c|}
\hline Independent variable & B & $S \otimes E$ & $\mathrm{~B} \bigotimes$ & $\begin{array}{l}t \\
\text { values }\end{array}$ & $P$ \\
\hline Constant & 115.217 & 1.590 & - & 72.468 & $<0.001$ \\
\hline$>36$ years old & -7.092 & 1.440 & -0.146 & -4.925 & $<0.001$ \\
\hline Undergraduate & 2.007 & 0.670 & 0.053 & 2.997 & 0.003 \\
\hline Can use database to search literature & 6.825 & 1.058 & 0.173 & 6.454 & $<0.001$ \\
\hline Use most of spare time to learn professional knowledge & 7.860 & 0.930 & 0.148 & 8.456 & $<0.001$ \\
\hline Primary hospital & -7.076 & 1.166 & -0.104 & -6.068 & $<0.001$ \\
\hline Read 1-3 medical literatures in the last month & 4.169 & 0.702 & 0.111 & 5.938 & $<0.001$ \\
\hline Read more than 3 medical literatures in the last month & 4.500 & 1.228 & 0.069 & 3.663 & $<0.001$ \\
\hline Don't participate in information literacy training & -5.982 & 0.770 & -0.160 & -7.765 & $<0.001$ \\
\hline $\begin{array}{l}\text { Be not clear whether to participate in information literacy } \\
\text { training }\end{array}$ & -7.105 & 0.865 & -0.166 & -8.215 & $<0.001$ \\
\hline
\end{tabular}

\section{Discussion}

This is the first study that investigated the current situation of the information literacy of nurses in multi-center hospitals in China. Through the investigation of 3,011 nurses, we found that the level of information literacy of nurses in Shaanxi Province was low, and there was a big gap between nurses' information literacy in hospitals of different levels $(P<0.001)$ which shows that it is necessary to speed up the cultivation of nurses' information literacy, especially for nurses in primary hospitals.

The information literacy of nurses can help them effectively obtain valuable information in clinical nursing work and make correct information decision timely, which is closely related to the quality of clinical nursing service [20, 21]. Studies have found that good information literacy of nurses is conducive to promoting the health of patients $[22,23]$. Therefore, it is necessary and meaningful to make clear the status of nurses' information literacy, find out the influencing factors, and give targeted guidance. However, in our study, the level of information literacy of nurses was low; We can see from Table 1 that there are significant differences in the educational background, living conditions, marital status, professional titles, learning situation, and the mastery of information retrieval knowledge of nurses among these hospitals $(P<0.001)$. At present, most of the medical hospitals in China have carried on informatization construction [24], but there is a big gap between hospitals of different levels [25], especially primary hospitals and clinics, which are short of the construction of quality management system of medical information, as well as information of medical quality control hardware facilities [26, 27]. This was an important reason for the low level of information literacy of nurses

In the multiple linear regression equation in Table 5, we also found that age and education background were other important factors affecting nurses' information literacy, which was similar to Nowrouzi's [28] findings that highly educated nurses have better working ability, so they can better master information skills and have a high level of information literacy. Compared with older nurses, younger nurses were more likely to apply information 
equipment and master information knowledge and skills, so their information literacy level was higher. Therefore, in the process of information literacy training, educators should pay more attention to the improvement of the ability of elderly and low degree nurses.

In our study, $29 \%$ of nurses participated in information literacy training, higher than $20 \%$ reported in Singapore [15] which was related to the Healthy China 2030 strategy to speed up the construction of medical team and personnel training [29]. A longitudinal study on nurse information training found that nurses' ability of information seeking and management was significantly improved after five months of training [13]. Therefore, it is necessary to strengthen the training of nurses' information literacy [30]. Nurses who had received relevant information training thought that it was adequate to meet the needs of clinical nursing work [31]. The government should actively organize information literacy training, promote clinical continuing education of information literacy, pay attention to the teaching of information literacy in the training process of nursing students [32-35] strengthen information support for hospitals, especially primary hospitals, and provide financial support and hardware facilities [36].

In order to speed up the process of informatization, nursing managers should fully realize the importance of information literacy in clinical nursing work [37,38]. Primary hospitals in China are mainly located in township hospitals and community health service stations, with low information level and lagging medical development $[39,40]$. The score of information literacy of primary nurses in these hospitals was far lower than that of the secondary and tertiary hospitals. With the proposal of healthy China strategy; to promote the health level of the whole people [41, 42], it is necessary to promote the information construction, improve the electronic medical records of residents, and construct health records and information network in primary hospital [43].

On the other hand, nurses should strengthen the accumulation of information literacy in clinical nursing work which is consistent with Jindal's [44] findings that there was an internal relationship between nurses' information literacy and reading behavior. Nurses should keep good reading habits in spare time, especially reading more about the advanced medical literature. With the development of evidence-based nursing which has higher requirements for literature index and retrieval [45], it is necessary for nurses to master good literature retrieval ability to carry out evidence-based nursing in clinical work [22]. Application of information index is one of the important ability of nurses' information literacy, through which nurses can learn the latest frontier dynamic knowledge in professional field $[46,47]$. Therefore, nurses themselves should strengthen professional learning and skills development, and constantly improve the level of information literacy.

There are some limitations in this study. First of all, this study was only limited to nurses in Shaanxi Province. Affected by geographical location, economic development and medical level, it can not represent the overall information literacy level of Chinese nurses. Moreover, the questionnaire was self-reported by nurses, which has certain subjective bias. Therefore, further subjective and objective evaluation method in hospitals of different regional provinces and cities are required.

\section{Conclusion}

Through the investigation on the information literacy of nurses, we not only clarified the information literacy level of nurses in Shaanxi Province, but also found the deficiencies of nurses' information literacy. Moreover, we also clarified the gap of information literacy of nurses in hospitals of different levels. In the information medical era, we should pay attention to the improvement of nurses' information literacy. Our research emphasizes that clinical 
nurses and nursing managers should pay attention to the cultivation of nurses' information literacy, and improve the ability of information identification, analysis, processing and utilization in big data medicine. Nursing staff should timely understand and master the latest research results in the professional field to improve the clinical nursing ability and improve the quality of nursing service.

\section{Declarations}

\section{Ethics approval and consent to participate}

This study was conducted according to the ethical guidelines described in the Helsinki Declaration (World Medical Association, 2013). Before the survey, we explained the purpose and significance of the study to the participants, asked for their verbal and written consent before conducting the investigation and signed the informed consent form of all participants. During the investigation, participants could terminate and withdraw from the investigation at any time. The questionnaire was completed anonymously. And the data collected were only used for our research, not for any other purpose.

\section{Consent for publication}

Not applicable.

\section{Availability of data and materials}

The datasets used and/or analysed during the current study available from the corresponding author on reasonable request.

\section{Competing interests}

No potential conflict of interst was reported by authors.

\section{Funding}

This study was supported with grants of the Key Research and Development plan of Shaanxi Province: General Projects - social development field (Grant 2020SF-280). The funder had took part in the design of the study; collection and analysis data.

\section{Authors' contributions}

WC performed the analysis and drafted the manuscript. YLR, CHF, JW, SL AND LHJ helped distribute questionnaires and collect data. FJY and ZLY critically revised the manuscript. DYL and HSZ aided in analysis and implications. All authors have read and approved the manuscript. 


\section{Acknowledgements}

We sincerely thank Lang Hongjuan, professor of the school of nursing, Air Force Medical University who actively contacted hospitals of different levels and made important contributions to this study. We also gratefully acknowledged all of the nurses in 30 hospitals of different grades who willingly participated in the survey.

\section{Author's Information}

${ }^{1}$ Air Force Medical University, No.169 Changle West Road, Xian, Shaanxi, China. ${ }^{2}$ Xianyang Central Hospital, No.78 Renmin East Road, Weicheng District, Xianyang City, Shaanxi, China. ${ }^{3}$ Shaanxi Provincial Hospital of traditional Chinese medicine, No.2 xihuamen, Lianhu District, Xi'an, Shaanxi, China. ${ }^{4}$ Tangdu Hospital, No.1 Xinsi Road, Baqiao District, Xi'an, Shaanxi, China.

\section{References}

1. Beckmann JS, Lew D: Reconciling evidence-based medicine and precision medicine in the era of big data: challenges and opportunities. Genome medicine 2016, 8(1):134.

2. Silva-Fernández L, Carmona L: Meta-analysis in the era of big data. Clinical rheumatology 2019, 38(8):20272028.

3. de Los Campos G, Vazquez Al, Hsu S, Lello L: Complex-Trait Prediction in the Era of Big Data. Trends in genetics : TIG 2018, 34(10):746-754.

4. Berger ML, Doban V: Big data, advanced analytics and the future of comparative effectiveness research. Journal of comparative effectiveness research 2014, 3(2):167-176.

5. Sharma A, Harrington RA, McClellan MB, Turakhia MP, Eapen ZJ, Steinhubl S, Mault JR, Majmudar MD, Roessig L, Chandross KJ et al: Using Digital Health Technology to Better Generate Evidence and Deliver Evidence-Based Care. Journal of the American College of Cardiology 2018, 71(23):2680-2690.

6. Gephart SM, Davis M, Shea K: Perspectives on Policy and the Value of Nursing Science in a Big Data Era. Nursing science quarterly 2018, 31(1):78-81.

7. Melnyk BM, Gallagher-Ford L, Zellefrow C, Tucker S, Thomas B, Sinnott LT, Tan A: The First U.S. Study on Nurses' Evidence-Based Practice Competencies Indicates Major Deficits That Threaten Healthcare Quality, Safety, and Patient Outcomes. Worldviews on evidence-based nursing 2018, 15(1):16-25.

8. Drummond FJ, Reidy M, von Wagner C, Livingstone V, Drennan J, Murphy M, Fowler C, Saab MM, O'Mahony M, Hegarty J: Health Literacy Influences Men's Active and Passive Cancer Information Seeking. Health literacy research and practice 2019, 3(3):e147-e160.

9. Carroll AJ, Hallman SJ, Umstead KA, McCall J, DiMeo AJ: Using information literacy to teach medical entrepreneurship and health care economics. Journal of the Medical Library Association : JMLA 2019, 107(2):163-171.

10. Coster $\mathrm{S}$, Watkins $\mathrm{M}$, Norman IJ: What is the impact of professional nursing on patients' outcomes globally? An overview of research evidence. International journal of nursing studies 2018, 78:76-83.

11. Bazrafkan L, Hayat AA, Abbasi K, Bazrafkan A, Rohalamini A, Fardid M: Evaluation of information literacy status among medical students at Shiraz University of Medical Sciences. Journal of advances in medical 
education \& professionalism 2017, 5(1):42-48.

12. Zhong Z, Hu D, Zheng F, Ding S, Luo A: Relationship between information-seeking behavior and innovative behavior in Chinese nursing students. Nurse education today 2018, 63:1-5.

13. Sleutel MR, Bullion JW, Sullivan R: Tools of the trade: Improving nurses' ability to access and evaluate research. Journal of nursing management 2018, 26(2):167-171.

14. Wahoush O, Banfield L: Information literacy during entry to practice: information-seeking behaviors in student nurses and recent nurse graduates. Nurse education today 2014, 34(2):208-213.

15. Mokhtar IA, Majid S, Foo S, Zhang X, Theng YL, Chang YK, Luyt B: Evidence-based practice and related information literacy skills of nurses in Singapore: an exploratory case study. Health informatics journal 2012, 18(1):12-25.

16. Wadson K, Phillips LA: Information literacy skills and training of licensed practical nurses in Alberta, Canada: results of a survey. Health information and libraries journal 2018, 35(2):141-159.

17. Tarrant M, Dodgson JE, Law BV: A curricular approach to improve the information literacy and academic writing skills of part-time post-registration nursing students in Hong Kong. Nurse education today 2008, 28(4):458-468.

18. Lin KY: Evaluating the effect of a clicker in an information literacy course for college nursing students in Taiwan. Computers, informatics, nursing : CIN2015, 33(3):115-121.

19. Sánchez GA, Carmona MB, Pérez OE, Del Socorro García VM: Information Literacy in Nursing Students of Fes Zaragoza Unam. Studies in health technology and informatics 2018, 250:72-73.

20. Garrett B, Klein G: Value of wireless personal digital assistants for practice: perceptions of advanced practice nurses. Journal of clinical nursing 2008, 17(16):2146-2154.

21. Mugomeri E, Chatanga P, Maibvise C, Masitha M: Assessment of Computer Literacy of Nurses in Lesotho. Computers, informatics, nursing : CIN 2016, 34(11):528-534.

22. Cho H, Han K, Park BK: Associations of eHealth literacy with health-promoting behaviours among hospital nurses: A descriptive cross-sectional study. Journal of advanced nursing 2018, 74(7):1618-1627.

23. Barnard A, Nash R, O'Brien M: Information literacy: developing lifelong skills through nursing education. The Journal of nursing education 2005, 44(11):505-510.

24. Qin J, Liu H, Dong Y, Yi Q, Zhang C, Yu S, Huang Q, Zhao Y, Mo S: [Integration of clinical pathway construction and hospital information system in intensive care unit is the core of digitalized hospital: experience of clinical pathway construction in Liuzhou Worker's Hospital from 2016 to 2018]. Zhonghua wei zhong bing ji jiu yi xue 2019, 31(1):102-107.

25. MacLeod MLP, Stewart NJ, Kosteniuk JG, Penz KL, Olynick J, Karunanayake CP, Kilpatrick K, Kulig JC, MartinMisener R, Koren I et al: Rural and Remote Registered Nurses' Perceptions of Working Beyond Their Legislated Scope of Practice. Nursing leadership (Toronto, Ont) 2019, 32(1):20-29.

26. Chen M, Qian D, Feng Z, Si L: Is outpatient care benefit distribution of government healthcare subsidies equitable in rural ethnic minority areas of China? Results from cross-sectional studies in 2010 and 2013. BMJ Open 2018, 8(2):e019564.

27. Emergency Medical Branch Of Chinese Medical A, Emergency Physician Branch Of Chinese Medical Doctor A, Emergency Union Of China County H, Editorial Committee Of Chinese Journal Of Emergency M, Hospital Management Research Institute Of National Health Care C, Writing Group Of Expert Consensus On The 
Construction Of Emergency Department In Chinese County H, Zhang W, Li Z, Xing Y, Chen B et al: [Expert consensus on the construction of emergency department in Chinese county hospitals]. Zhonghua wei zhong bing ji jiu yi xue 2019, 31(5):528-535.

28. Nowrouzi B, Lightfoot N, Carter L, Larivière M, Rukholm E, Schinke R, Belanger-Gardner D: Work ability and work-related stress: A cross-sectional study of obstetrical nurses in urban northeastern Ontario. Work (Reading, Mass) 2015, 52(1):115-122.

29. Tan X, Liu X, Shao H: Healthy China 2030: A Vision for Health Care. Value in health regional issues 2017, 12:112-114.

30. Wallace MC, Shorten A, Crookes PA: Teaching information literacy skills: an evaluation. Nurse education today 2000, 20(6):485-489.

31. Eley R, Fallon T, Soar J, Buikstra E, Hegney D: The status of training and education in information and computer technology of Australian nurses: a national survey. Journal of clinical nursing 2008, 17(20):27582767.

32. Chiou SF, Su HC, Huang EW: [The Application of Information and Communication Technology (ICT) in Nursing Education]. Hu li za zhi The journal of nursing 2017, 64(6):5-11.

33. Fetter MS: Improving information technology competencies: implications for psychiatric mental health nursing. Issues in mental health nursing 2009, 30(1):3-13.

34. Willmer M: Promoting practical clinical management learning: the current situation about Information and Communications Technology capability development in student nurses. Journal of nursing management 2005, 13(6):467-476.

35. Curran CR: Faculty development initiatives for the integration of informatics competencies and point-of-care technologies in undergraduate nursing education. The Nursing clinics of North America 2008, 43(4):523-533, v.

36. Dowding D: Are nurses expected to have information technology skills? Nursing management (Harrow, London, England : 1994) 2013, 20(5):31-37.

37. Jeong SH, Kim HK: Health literacy and barriers to health information seeking: A nationwide survey in South Korea. Patient education and counseling 2016, 99(11):1880-1887.

38. Horntvedt MT, Nordsteien A, Fermann T, Severinsson E: Strategies for teaching evidence-based practice in nursing education: a thematic literature review. BMC medical education 2018, 18(1):172.

39. Chang Y, Chusri S, Sangthong R, McNeil E, Hu J, Du W, Li D, Fan X, Zhou H, Chongsuvivatwong V et al: Clinical pattern of antibiotic overuse and misuse in primary healthcare hospitals in the southwest of China. PLoS One 2019, 14(6):e0214779.

40. Zhang T, Xu Y, Ren J, Sun L, Liu C: Inequality in the distribution of health resources and health services in China: hospitals versus primary care institutions. International journal for equity in health 2017, 16(1):42.

41. Li L, Fu H: China's health care system reform: Progress and prospects. The International journal of health planning and management 2017, 32(3):240-253.

42. Li LM: [Role of public health in building Healthy China]. Zhonghua liu xing bing xue za zhi = Zhonghua liuxingbingxue zazhi 2018, 39(7):867-872.

43. Heijmans N, van Lieshout J, Wensing M: Information exchange networks of health care providers and evidence-based cardiovascular risk management: an observational study. Implementation science : IS 2017, 
12(1):7.

44. Jindal P, MacDermid JC: Assessing reading levels of health information: uses and limitations of flesch formula. Education for health (Abingdon, England) 2017, 30(1):84-88.

45. Jelsness-Jørgensen LP: Does a 3-week critical research appraisal course affect how students perceive their appraisal skills and the relevance of research for clinical practice? A repeated cross-sectional survey. Nurse education today 2015, 35(1):e1-5.

46. Mehta N, Gupta A, Nissan M: All I Have Learned, I Have Learned from Google: Why Today's Facial Rejuvenation Patients are Prone to Misinformation, and the Steps We can take to Contend with Unreliable Information. Facial plastic surgery : FPS 2019, 35(4):387-392.

47. Parnell TA, Stichler JF, Barton AJ, Loan LA, Boyle DK, Allen PE: A concept analysis of health literacy. Nursing forum 2019, 54(3):315-327.

\section{Supplementary Files}

This is a list of supplementary files associated with this preprint. Click to download.

- Additionalfile1.docx 